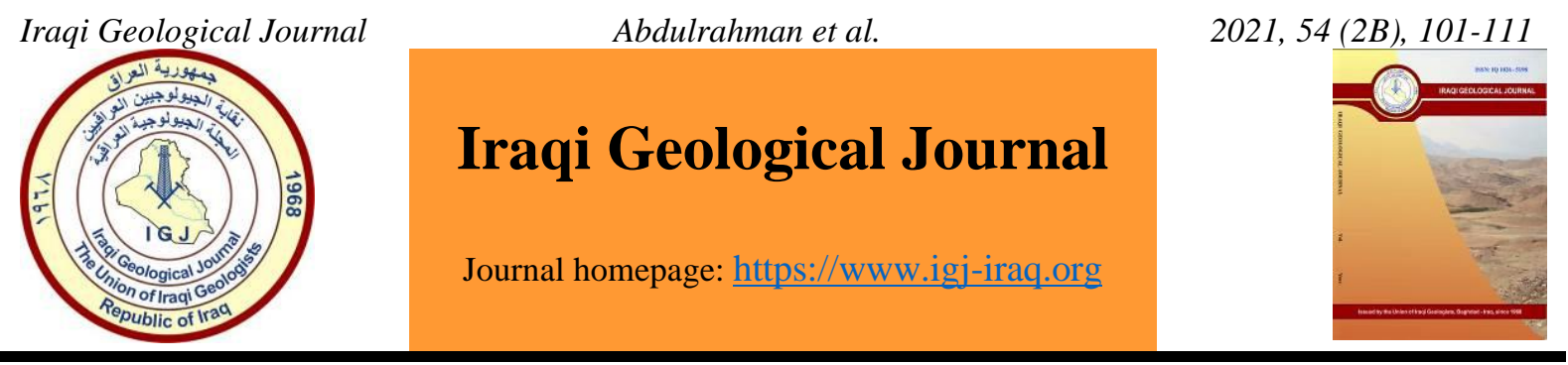

\title{
Effect of Discharge on Water Quality in Euphrates River Between Hit and Ramadi, Iraq
}

\author{
May F. Abdulrahman ${ }^{1}$, Yasir M. Yosif ${ }^{2}$, Wahran M. Saod ${ }^{1 * *}$ and Emad Abdulrahman Al-Heety ${ }^{3}$ \\ ${ }^{1}$ Department of Chemistry, College of Science, University of Anbar, Anbar, Iraq \\ ${ }^{2}$ Department of Biology, College of Science, University of Anbar, Anbar, Iraq \\ ${ }^{1}$ Department of Chemistry, College of Science, University of Anbar, Anbar, Iraq \\ ${ }^{3}$ Department of Applied Geology, College of Science, University of Anbar, Iraq \\ * Correspondence: sc.wahran.s@uoanbar.edu.iq
}

Received: 10 April 2021; Accepted: 12 June 2021; Published: 31 August 2021

\begin{abstract}
The objective of this study was to determine the relationship between water drainage rates in Hit and Ramadi cities and the water quality of the Euphrates River. The studied area of Euphrates River extends from Hit to Ramadi, where two sampling stations were selected monthly in 2012, 2013, and 2018. The results indicate variations and decreasing in the monthly discharge rate of the study period; the year 2012 had higher discharge rate values than 2013, which in turn was higher than in 2018, for both gauging stations. Our results indicate that with decreasing discharge trends, some selected water quality parameters had an increasing trend. During the selected years, there was an increase in levels of sulfate, nitrate, dissolved oxygen, magnesium, and turbidity in the Ramadi station compared to the Hit station, as the rate of discharge of the river increases in the former. A positive significant correlation between discharge rate and dissolved oxygen and dissolved solids were reported. The Haditha Dam and its reservoir affect the downstream discharge rate and in turn the water quality at Hit and Ramadi Cities.
\end{abstract}

Keywords: Discharge; Euphrates; WQI; Pollution

\section{Introduction}

Freshwater is a necessity for humans as well as other organisms. The water quality is a matter of global concern for environmental health, especially in aquatic ecosystems (Chien \& Pierce, 2018). The quality of river water is affected by anthropogenic activities such as urban, industrial and agricultural activities, as well as natural processes including weathering, erosion of the earth's crustal material and climate change (Hamid et al., 2020). The physical and chemical parameters of water are also influenced by stream flow discharge, both concentrations and total loads (Prathumratana et al., 2008). A significant variation in water quality parameters can be caused by surface runoff generated from storm events (Chen \& Lu, 2014); (Rostami et al., 2018). Climate change leads to an increase in the frequency and severity of droughts, which in turn decrease flow rates and their fluctuation (Hanslík et al., 2016). A significant change in water quality may result from hydrological droughts (Momblanch et al., 2015). The impact of

DOI: $\underline{10.46717 / i g j .54 .2 B .9 M s-2021-08-29}$ 
the stream flow rate on water quality parameters has been investigated for many rivers and watersheds around the world, for example, the Pinang River in Malaysia (Yunus \& Nakagoshi, 2004), the Lower Mekong River along the China-Laos-Thailand borders (Prathumratana et al., 2008), the Vltava River in Czech Republic (Hanslík et al., 2016), and the Upper Esopus Creek Watershed of New York, USA (Chien \& Pierce, 2018). The effect of the flow rate of the Euphrates River on its water quality has been investigated by several author's studies on physical and chemical water quality parameters (Rahi \& Halihan, 2010; Al-Ansari et al. 2018; Chabuk et al. 2020). Studies have found that the water quality and quantity of the Euphrates has steadily deteriorated over several decades and continues to be affected by both natural factors like climate change and human activities such as sewage and industrial discharge and agricultural runoff (Al-Bahrani, 2014; Al-Rekabi \& Al-Ghanimy, 2015; Venturi \& Capozzoli, 2017, Al-Paruany et al., 2017). In recent years, the Euphrates has suffered from a decreasing discharge flow rate, causing problems of both water quantity and quality. The mean annual discharge of the Euphrates was 983-1046 m3/s along the Iraqi-Syria border before dam construction (Hussein \& Bomola, 2013). The crisis has been worsened not only due to the construction of large dams and reservoirs upstream, but also as a result of very low rainfall in Iraq; consequently, the discharge from this river has continuously decreased over the last four decades. The aim of the current study is to investigate the effects of stream flow rate/discharge on the water quality parameters of the Euphrates River Iraq, the cities of Hit and Ramadi.

\section{Materials and Methods}

\subsection{Study Location and Water Sampling}

The Euphrates originates in Turkey, runs through Syria, enters Iraq from the western border, and discharges in the Shatt Al-Arab. The total area of the Euphrates is $440,000 \mathrm{~km}^{2}$, of which $28 \%$ is in Turkey $\left(123,200 \mathrm{~km}^{2}\right), 22 \%$ in Syria $\left(96,800 \mathrm{~km}^{2}\right)$ and $47 \%$ in Iraq $\left(206,800 \mathrm{~km}^{2}\right)$ (Mhaisen et al., 2017). Two sites - Hit $\left(\mathrm{S}_{1}\right)$ and Ramadi $\left(\mathrm{S}_{2}\right)$ - in Anbar Governorate, West Iraq were chosen for sampling water from the Euphrates River (Fig .1). These sites were selected because of the availability of discharge data. The samples were collected monthly in the years of 2012, 2013 and 2018.

\subsection{Field and Laboratory Testing}

At the field sites, samples were obtained by filling $(1 \mathrm{~L})$ sterile polyethylene bottles from the middle of the river. For each sections date, an average for the measured parameters was obtained by taking samples from three sites at each station. The physic-chemical was analysis performed generally according to accepted techniques, either in the field or in a laboratory. These parameters were turbidity (Tur), dissolved oxygen (DO), total dissolved salts (TDS), sulphate ion ( $\left.\mathrm{SO}^{2-}\right)$, Chloride ion $\left(\mathrm{Cl}^{-}\right)$, nitrate ion $\left(\mathrm{NO}_{3}{ }^{-}\right)$, total hardness as carbonates (T.H), calcium $\left(\mathrm{Ca}^{2+}\right)$ and magnesium $\left(\mathrm{Mg}^{2+}\right)$. Certain specific variables had to be measured in the field using a handheld meter or other additional field technology. The remainder of the analysis was completed in a laboratory environment with the correct equipment. The sample temperature, $\mathrm{pH}$ and specific conductivity had to be tested in the field to capture any sample changes during transportation to the laboratory. The discharge rates of the Euphrates at gauging stations at the Hit and Ramadi sites for the years 2012, 2013 and 2018 were obtained from the Directorate of Water Resources in Anbar Governorate, Table 1. 


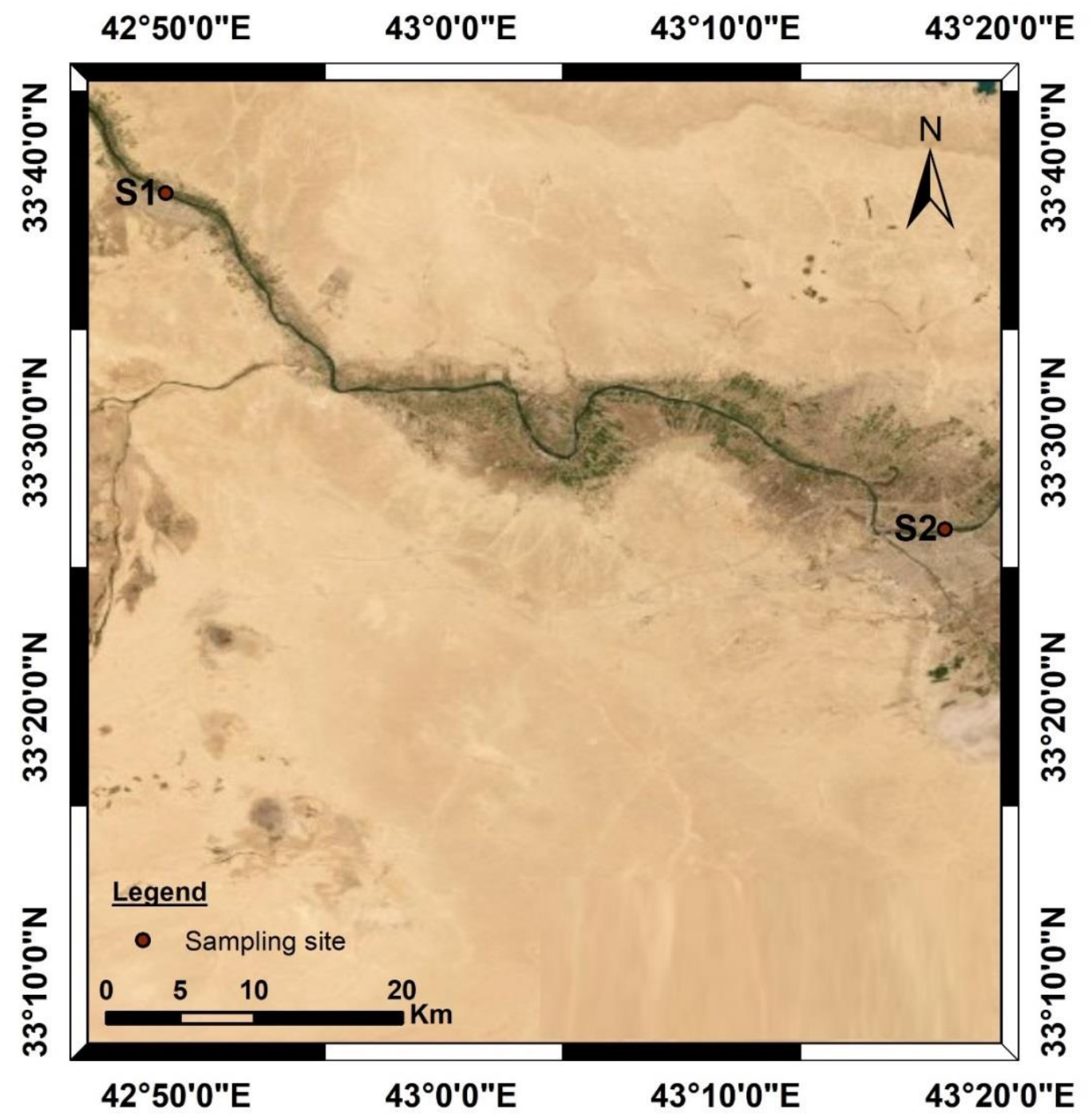

Fig.1. Location map showing sampling regions in the study area

Table 1. Discharge rates $\left(\mathrm{m}^{3} / \mathrm{s}\right)$ of Euphrates River at Hit and Ramadi gauging stations

\begin{tabular}{|c|c|c|c|c|c|c|}
\hline \multirow[t]{2}{*}{ Month } & \multicolumn{3}{|c|}{ Hit gauging station } & \multicolumn{3}{|c|}{ Ramadi gauging station } \\
\hline & 2012 & 2013 & 2018 & 2012 & 2013 & 2018 \\
\hline January & 385 & 400.2 & 319.6 & 242 & 260 & 382 \\
\hline February & 423.4 & 460.2 & 283.2 & 234 & 318 & 309 \\
\hline March & 454.2 & 361.9 & 234.1 & 404 & 352 & 241 \\
\hline April & 357.8 & 250.5 & 233.7 & 362 & 319 & 220 \\
\hline May & 362 & 273.8 & 168 & 339 & 331 & 200 \\
\hline June & 563.3 & 430.5 & 222.5 & 507 & 542 & 232 \\
\hline July & 565.5 & 413.5 & 296.1 & 657 & 594 & 280 \\
\hline August & 602.6 & 386.5 & 272 & 593 & 533 & 274 \\
\hline September & 577.7 & 401.4 & 249.7 & 475 & 463 & 266 \\
\hline October & 513.6 & 401.7 & 245.7 & 458 & 521 & 280 \\
\hline November & 451.1 & 416.2 & 236.9 & 467 & 377 & 306 \\
\hline December & 332.2 & 348 & 184.1 & 394 & 448 & 254 \\
\hline
\end{tabular}




\section{Results and Discussion}

\subsection{Discharge rates}

Results of the descriptive statistics of the discharge rates are listed in Table 2. The obtained results show that the monthly discharge rate for the year 2012 was higher than it was in 2013, which in turn was higher than in 2018, for both gauging stations (Figs. 2. and 3).

Table. 2. Results of the descriptive statistics of discharge rate of Euphrates River at Hit and Ramadi gauging stations.

\begin{tabular}{lllc}
\hline Year & $\begin{array}{l}\text { Statistic } \\
\text { Measure }\end{array}$ & \multicolumn{1}{c}{ Gauge stations } \\
\hline \multirow{4}{*}{2012} & Hit & Ramadi \\
& Mean & 465.7 & 427.66 \\
& Minimum & 332.2 & 234 \\
& Maximum & 602.6 & 657 \\
& Std.Dev. & 96.26 & 126.76 \\
& Coef.Var. & 20.67 & 29.64 \\
& Mean & 378.7 & 421.5 \\
& Min. & 250.5 & 260 \\
2013 & Max & 460.2 & 594 \\
& Std.Dev. & 61.91 & 109.26 \\
& Coef.Var. & 16.35 & 25.92 \\
& Mean & 245.46 & 270.33 \\
& Min. & 168 & 200 \\
& Max & 319.6 & 382 \\
& Std.Dev. & 43.52 & 48.17 \\
& Coef.Var. & 17.73 & 17.82 \\
\hline
\end{tabular}

Analysis of variance (ANOVA) results between monitoring years at the Hit discharge gauging stations showed that the p-values were 0.0001 . This result indicates there was a significant difference (at $\mathrm{p}<0.05$ ) in discharge rates during the monitoring years. A similar result was reported at Ramadi station. The analysis of variance (ANOVA) results between the discharge rate of the Euphrates at Hit and Ramadi gauging stations showed insignificant differences during the monitoring years. This result reflects the absence of a local discharge source within the study area, which may have reflected the decrease in upstream water resources and an absence or scarcity of local resources within the study area due to the lack of precipitation. Many authors have found that the large dams and reservoirs affect the Euphrates' downstream discharge and flow (Yang et al., 2015; Lee et al., 2019; Thu Ha et al., 2020).

\subsection{Water Quality Parameters}

The results of the descriptive statistics for the water quality parameters data at Hit and Ramadi stations during the monitoring years are presented in Tables 3 and 4 . According to Tables 3 and 4, above total solids dissolved were high, ranging between 353-772.75 mg/L, in excess of World Health Organization limits (WHO), at 500mg/L (WHO Press, 2011). calcium $\left(\mathrm{Ca}^{+2}\right)$ levels ranged from 55.85 to $125 \mathrm{mg} / \mathrm{L}$, well below the recommended levels of $150 \mathrm{mg} / \mathrm{L}$, while the magnesium $\left(\mathrm{Mg}^{+2}\right)$ levels ranged from 24.5 to $57.7 \mathrm{mg} / \mathrm{L}$, which was present in high concentrations in groundwater in the form of bicarbonate, sulphate or, to a lesser extent, chloride. Samples of water recorded high turbidity of 40.62 NTU, above the maximum permissible limit set by the WHO $(5 \mathrm{mg} / \mathrm{L})$, while the range of DO was 6.25 to $10.34 \mathrm{mg} / \mathrm{L}$. 


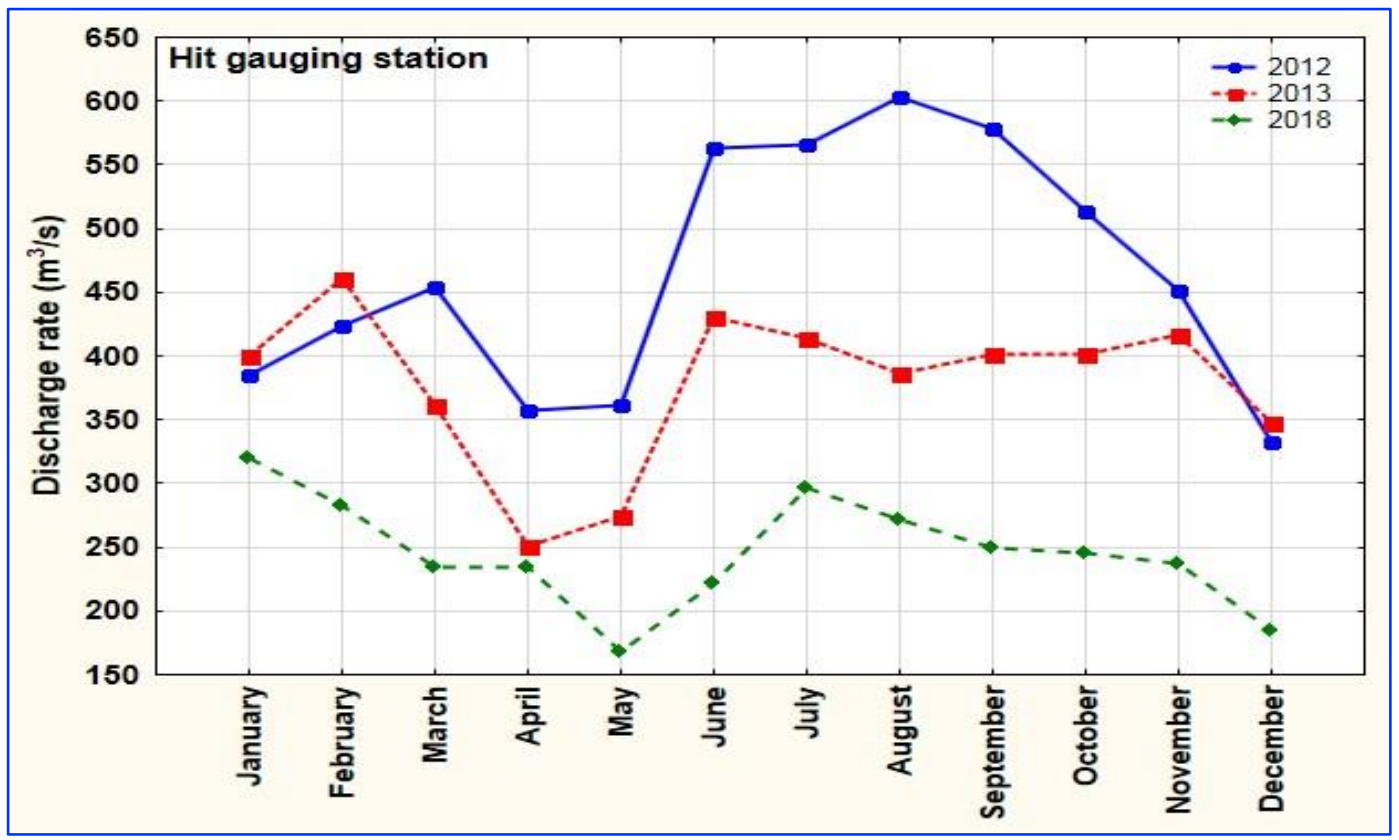

Fig .2. Monthly discharge rate at Hit discharge gauging stations.

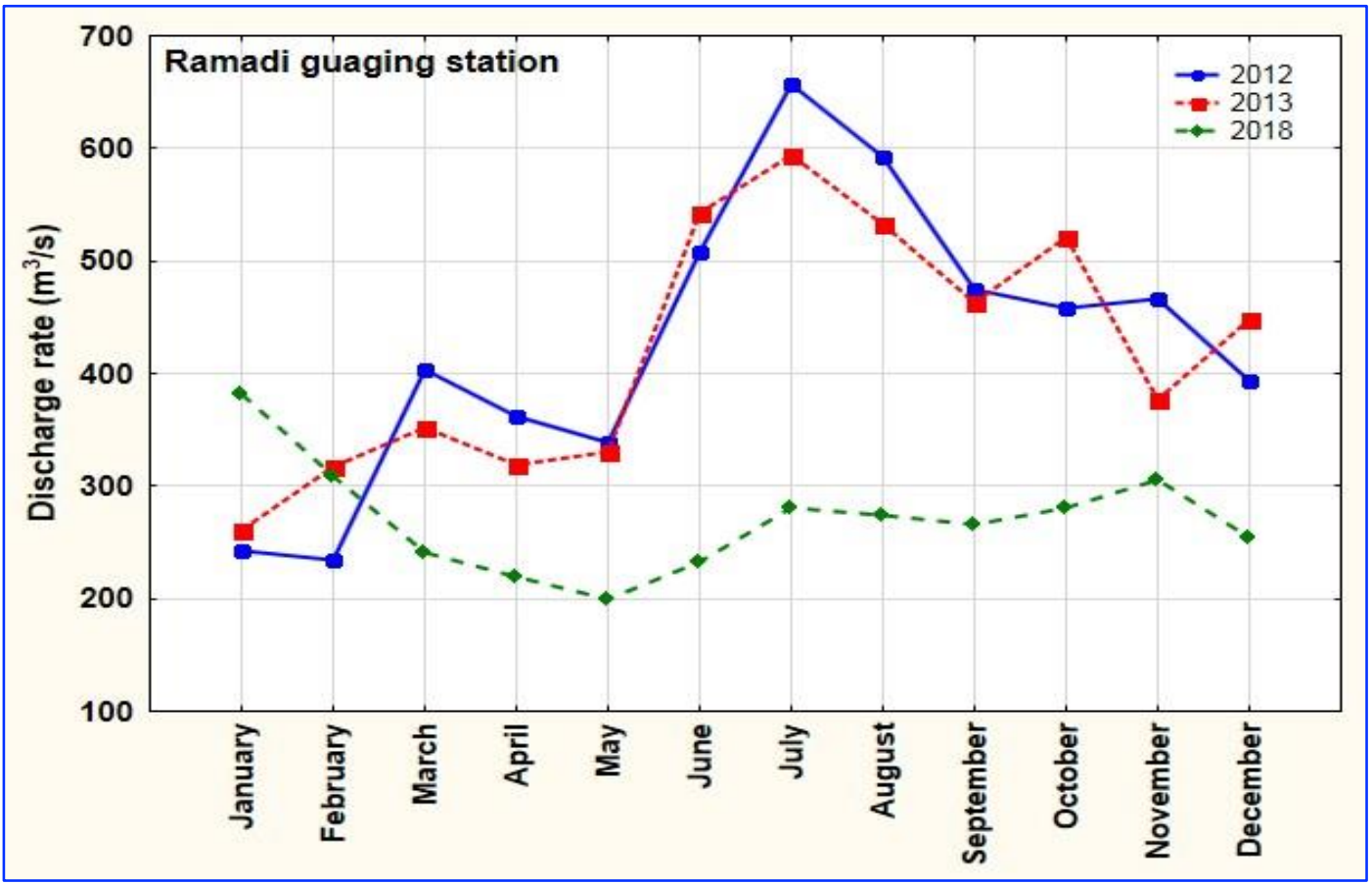

Fig.3. Monthly discharge rate at Ramadi discharge gauging stations

Surface water with hardness greater than $1000 \mathrm{mg} / \mathrm{L}$ is very hard and considered poor quality. Compared with WHO standards, the value of sulphates was observed above the standard limit in the range of 125.37 to $285 \mathrm{mg} / \mathrm{L}$. It is possible for the sulphate concentration to interact with different human organs with concentrations exceeding the acceptable limit of $200 \mathrm{mg} / \mathrm{L}$. Chloride concentrations less than $200 \mathrm{mg} / \mathrm{L}$ appeared within a range of 88.6 to $154 \mathrm{mg} / \mathrm{L}$. Nitrate (NO3) concentrations were detected at the monitoring stations from 2.25 to $4.55 \mathrm{mg} / \mathrm{L}$. Human 
Table .3. Descriptive statistics of water quality parameters at Hit station

\begin{tabular}{|c|c|c|c|c|c|c|c|c|c|}
\hline \multirow[t]{2}{*}{ Year } & \multirow[t]{2}{*}{ Statistic measure } & \multicolumn{8}{|c|}{ Water quality parameters } \\
\hline & & TDS & TUR. & DO & $\mathrm{Ca}^{+2}$ & $\mathrm{Mg}^{+2}$ & $\mathrm{Cl}^{-}$ & $\mathrm{SO}_{4}^{-2}$ & $\mathrm{NO}_{3}^{-}$ \\
\hline \multirow{7}{*}{2012} & & $\mathrm{mg} / \mathrm{l}$ & NTU & $\mathrm{mg} / \mathrm{l}$ & $\mathrm{mg} / \mathrm{l}$ & $\mathrm{mg} / \mathrm{l}$ & $\mathrm{mg} / \mathrm{l}$ & $\mathrm{mg} / \mathrm{l}$ & $\mathrm{mg} / \mathrm{l}$ \\
\hline & Mean & 671.04 & 29.76 & 7.14 & 81.12 & 41.11 & 123.23 & 217.98 & 3.78 \\
\hline & Minimum & 619.18 & 20.44 & 6.25 & 68.98 & 35.79 & 99.845 & 179.27 & 2.95 \\
\hline & Maximum & 751.88 & 40.62 & 7.83 & 96.83 & 47.80 & 154.12 & 256.71 & 4.49 \\
\hline & Std.Dev. & 41.77 & 5.97 & 0.63 & 8.33 & 4.87 & 15.18 & 26.67 & 0.50 \\
\hline & Coef.Var. & 6.22 & 20.06 & 8.82 & 10.27 & 11.84 & 12.31 & 12.23 & 13.30 \\
\hline & WHO guidelines & 500 & 5 & $2<$ & 150 & 50 & 200 & 200 & 10 \\
\hline \multirow{6}{*}{2013} & Mean & 552.18 & 15.72 & 9.33 & 79.03 & 34.00 & 108.21 & 186.3 & \multirow{2}{*}{3.25} \\
\hline & Min. & 507.6 & 4.85 & 7.95 & 69.05 & 28.75 & 88.6 & 164.15 & \\
\hline & $\operatorname{Max}$ & 616.6 & 25.6 & 10.3 & 88.65 & 46.35 & 130.75 & 219.7 & \multirow{4}{*}{$\begin{array}{l}3.95 \\
0.34 \\
10.63\end{array}$} \\
\hline & Std.Dev. & 32.45 & 7.75 & 0.93 & 6.93 & 6.079 & 13.50 & 13.57 & \\
\hline & Coef.Var. & 5.87 & 49.29 & 9.98 & 8.77 & 17.88 & 12.47 & 7.28 & \\
\hline & WHO guidelines & 500 & 5 & $2<$ & 150 & 50 & 150 & 200 & \\
\hline \multirow{6}{*}{2018} & Mean & 474.52 & 24.66 & 9.09 & 88.87 & 31.91 & 134.63 & 208.16 & 2.68 \\
\hline & Min. & 353 & 16.75 & 7.5 & 73 & 24.5 & 98 & 161 & 2.25 \\
\hline & Max & 669.24 & 31.55 & 10 & 125 & 51.5 & 145 & 285 & 3.35 \\
\hline & Std.Dev. & 126.95 & 5.73 & 0.80 & 21.43 & 7.58 & 16.37 & 48.96 & 0.31 \\
\hline & Coef.Var. & 26.75 & 23.23 & 8.84 & 24.11 & 23.76 & 12.15 & 23.52 & 11.58 \\
\hline & WHO guidelines & 500 & 5 & $2<$ & 150 & 50 & 200 & 200 & 10 \\
\hline
\end{tabular}

Human activities that can increase nutrient levels in aquatic systems include Human activities that can increase nutrient levels in aquatic systems include atmospheric deposition of nitrogen from fossil fuel combustion, agriculture, and industrial activities (Thu Ha et al., 2020). An increase in nutrient concentration with a low-flow situation is particularly harmful if it occurs at a time of the biological activity of living organisms, such as in spring or summer (Lawrence \& Gresens, 2004). Stagnant water eutrophication has become a major ecological and environmental problem (Torrecilla et al., 2005; Smith et al., 1999). However, nutrient addition can also lead to a series of abnormal ecosystem responses, including enhancing primary production in streams, predominantly of benthic algae, and enhancing the growth of pelagic algae (Camargo et al., 2005). Even nitrogen can be toxic to aquatic animals and impair their ability to survive, grow, and reproduce. The toxicity of nitrate can also weaken the survival, growth, and reproduction capacity of aquatic animals. High concentrations of ammonia, nitrite, and nitrate can also cause immense problems for marine animals (Camargo et al., 2004). Inorganic nitrogen pollution of groundwater and surface waters can also be detrimental to human health and the economy. Ingested nitrites and nitrates are harmful to humans because they produce elevated toxins and can stimulate infant methemoglobinemia, which may have a possible role in the development of different cancers and congenital defect. Not only can they be a reason for spontaneous abortions and respiratory tract infections, but they also play a part in the etiology of type 1 diabetes and in the evolution of goiter. Health risks can occur indirectly as a result of algal poisons, with symptoms ranging from nausea to acute intoxication syndromes (Camargo et al., 2005). The results of ANOVA tests on levels of water quality parameters recorded at the Hit and Ramadi stations during 2012, 2013 and 2018 are given in Table .5. 
Table .4. Descriptive statistics of water quality parameters at Ramadi station.

\begin{tabular}{llllllllll}
\hline Year & Statistic Measure & & \multicolumn{9}{c}{ Water quality parameters } \\
\hline \multirow{2}{*}{2012} & TDS & TUR. & $\mathrm{DO}$ & $\mathrm{Ca}^{+2}$ & $\mathrm{Mg}^{+2}$ & $\mathrm{Cl}^{-}$ & $\mathrm{SO}^{-2}$ & $\mathrm{NO}^{-}$ \\
& & $\mathrm{mg} / \mathrm{l}$ & $\mathrm{NTU}$ & $\mathrm{mg} / \mathrm{l}$ & $\mathrm{mg} / \mathrm{l}$ & $\mathrm{mg} / \mathrm{l}$ & $\mathrm{mg} / \mathrm{l}$ & $\mathrm{mg} / \mathrm{l}$ & $\mathrm{mg} / 1$ \\
& Mean & 538.71 & 15.43 & 8.74 & 87.13 & 33.99 & 141.45 & 212.22 & 2.85 \\
& Minimum & 459 & 8.92 & 6.75 & 28 & 28 & 101.75 & 164.50 & 2.45 \\
& Maximum & 680.37 & 22.42 & 9.75 & 127 & 50.87 & 148.5 & 291.75 & 3.3 \\
& Std.Dev. & 72.38 & 6.09 & 1.00 & 29.24 & 6.61 & 13.58 & 50.76 & 0.26 \\
& Coef.Var. & 13.43 & 39.45 & 11.46 & 33.56 & 19.45 & 9.60 & 23.92 & 9.30 \\
& WHO guidelines & 500 & 5 & $2<$ & 150 & 50 & 200 & 200 & 10 \\
& Mean & 676.96 & 29.16 & 7.21 & 75.36 & 41.40 & 124.18 & 200.91 & 3.37 \\
& Min. & 570.62 & 19.27 & 6.25 & 55.85 & 30.95 & 98.7 & 125.37 & 2.40 \\
& Max & 772.75 & 37.1 & 8.02 & 88.95 & 57.7 & 144.3 & 228.95 & 4.55 \\
& Std.Dev. & 62.31 & 6.13 & 0.65 & 11.18 & 7.49 & 16.96 & 33.17 & 0.82 \\
& Coef.Var. & 9.20 & 21.02 & 9.02 & 14.83 & 18.10 & 13.66 & 16.51 & 24.30 \\
& WHO guidelines & 500 & 5 & $2<$ & 150 & 50 & 200 & 200 & 10 \\
& Mean & 571.92 & 22.93 & 9.02 & 81.43 & 34.66 & 115.81 & 192.20 & 3.38
\end{tabular}

\subsection{Relation between Discharge Rate and Water Quality Parameters}

The quality of river water is influenced by various factors, including the quantity and quality that is discharged into them. The higher the amount of water that is discharged into rivers, the more pollutants are diluted; however, sometimes poor quality water is discharged into rivers, causing an increase in the concentration of pollutants, hence reversing the process. The ratios of mean values of water quality parameters for high discharge/low discharge, regression analyses were used to investigate the effects of the discharge rate of the Euphrates on its water quality at Hit and Ramadi gauging stations. The ratios of the mean values of water quality parameters for high discharge/low discharge rates for the given monitoring years (2012, 2013 and 2018) at Hit and Ramadi stations are shown in Fig. 4. During the monitoring years, there was an increase in levels of most parameters, such as sulphate, nitrate, dissolved oxygen, magnesium, and turbidity at the Ramadi station compared to the Hit station, as the rate of discharge of the river increases at the former site. Our study concurs with previous studies (Lee et al., 2019; Niazi et al., 2014; Yang et al., 2015). The data represent a clear increase in most parameters from the Hit station to the Ramadi station, indicating the presence of potential point sources of pollution or that the poor-quality water is flowing into the river. According to Fig. 5, the Euphrates' water quality varied across the two stations in the given monitoring years. These data indicate a positive significant correlation between the discharge rate and dissolved oxygen for Hit (2013) and total dissolved solids for Hit (2018), while chloride ion for Hit (2012) and Ramadi (2018), dissolved oxygen for Hit (2013), calcium ion for Ramadi (2013) and nitrate ion for Hit (2012) indicated negative significant correlations with the discharge rate. 
Table .5. Analysis of variance (ANOVA) between water quality parameters at Hit and Ramadi stations during the monitoring years

\begin{tabular}{|c|c|c|c|c|c|c|}
\hline Parameter & 2012 & & 2013 & & 2018 & \\
\hline & P-value & $\begin{array}{l}\text { Differences } \\
\text { at } p<0.05\end{array}$ & P-value & $\begin{array}{l}\text { Differences } \\
\text { at } p<0.05\end{array}$ & P-value & $\begin{array}{l}\text { Differences at } \\
p<0.05\end{array}$ \\
\hline TDS & 0.0004 & significant & 0.0000 & significant & 0.0169 & significant \\
\hline TUR. & 0.0002 & significant & 0.0001 & significant & 0.5977 & insignificant \\
\hline $\mathrm{Ca}^{+2}$ & 0.5194 & insignificant & 0.3494 & insignificant & 0.2711 & insignificant \\
\hline $\mathrm{Mg}^{+2}$ & 0.4863 & insignificant & 0.0163 & significant & 0.3464 & insignificant \\
\hline DO & 0.0002 & significant & 0.0000 & significant & 0.8547 & insignificant \\
\hline $\mathrm{Cl}^{-}$ & 0.0076 & significant & 0.0204 & significant & 0.0025 & significant \\
\hline $\mathrm{SO}_{4}{ }^{-2}$ & 0.7404 & insignificant & 0.1746 & insignificant & 0.2888 & insignificant \\
\hline $\mathrm{NO}_{3}^{-}$ & 0.0001 & significant & 0.6540 & insignificant & 0.0000 & significant \\
\hline
\end{tabular}
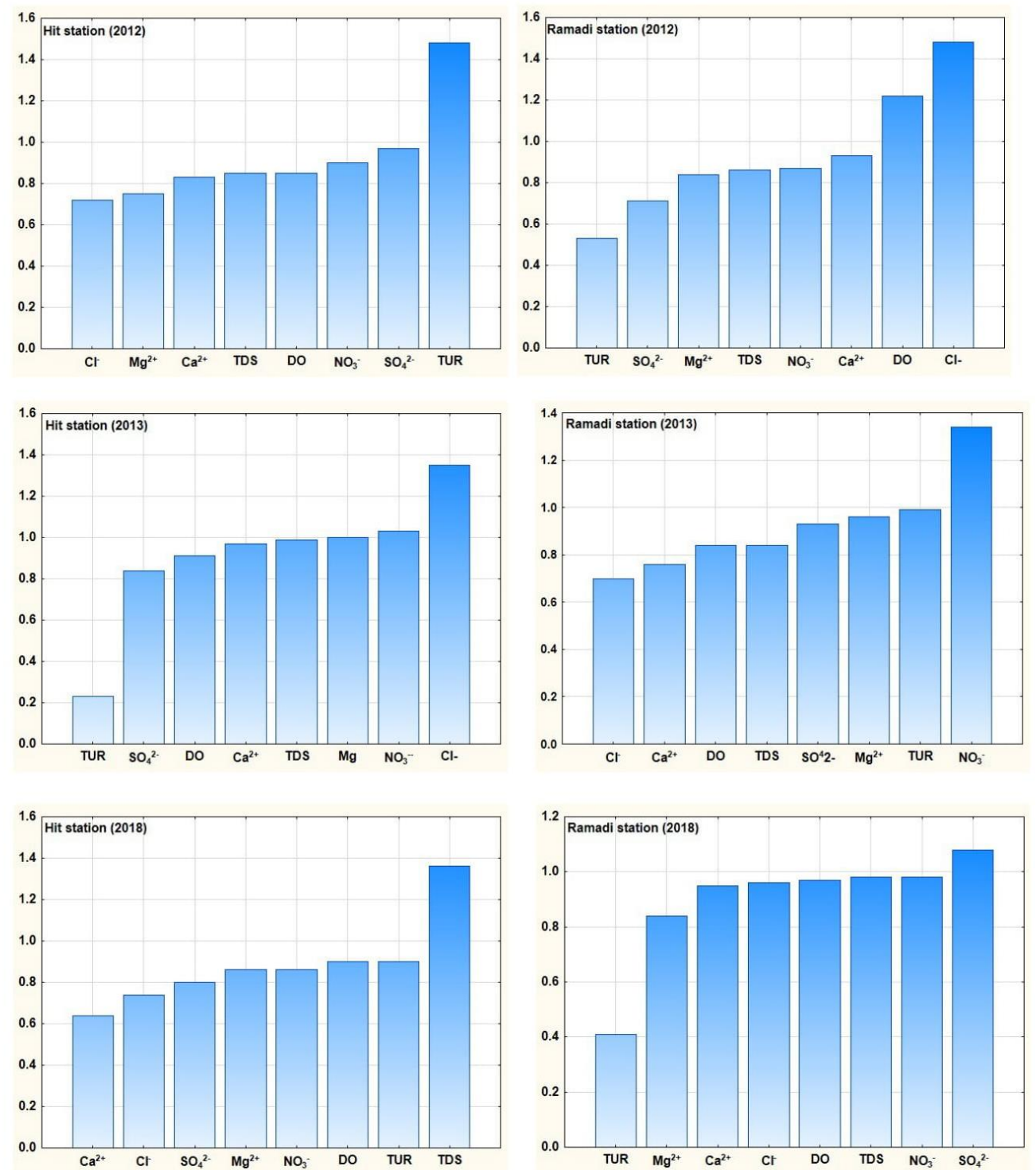

Fig.4. Ratios of mean values of water quality parameters for high discharge/low discharge in 2012,2013 and 2018 

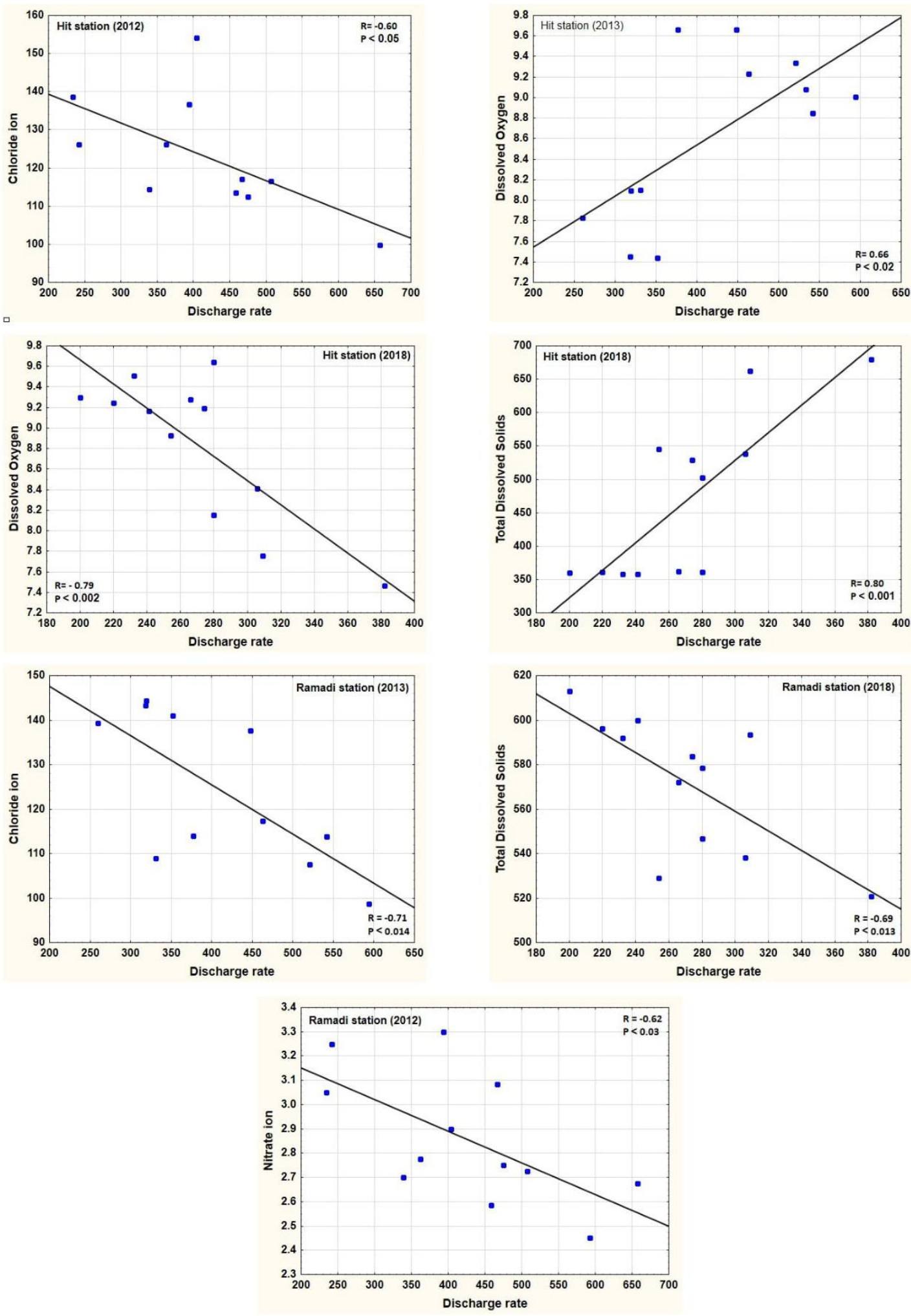

Fig.5. Relation between discharge rate and water quality parameters 


\section{Conclusions}

- There are insignificant differences in the discharge rate between Hit and Ramadi stations, reflecting the absence of important local sources of discharge within the study area.

- The increase or decrease in water quality parameters levels with the discharge rate depend on the quantity/or quality of the discharges.

- Haditha Dam and its reservoir affect the downstream discharge rate and, in turn, the quality of the water.

\section{Acknowledgements}

The authors sincerely appreciate the help of the workers in the service laboratory of the Anbar College of Science, and I am also very grateful to the workers in the Anbar Environment Directorate laboratory. The authors are very grateful to the Editor in Chief Prof. Dr. Salih M. Awadh, the Secretary of Journal Mr. Samir R. Hijab. and the Technical Editors for their great efforts and valuable comments.

\section{References}

Al-Ansari, N., Aljawad, S., Adamo, N., Sissakian, V. K., Laue, J., \& Knutsson, S., 2018. Water quality within the Tigris and Euphrates Catchments. Journal of Earth Sciences and Geotechnical Engineering, 8(3), 17929660.

Al-Bahrani, H. S., 2014. Water quality deterioration of the Euphrates River before entering Iraqi lands. WIT Trans. Ecol. Environ., 182, 3-14.

Al-Paruany, K. B., Al-Naseri, S., \& Al-Ajena, A. F., 2017. Distribution of environmental isotopes in the Euphrates River between Qaim-Fallujah, Western Iraq. Iraqi Geological Journal, 50(1), 12-27.

Al-Rekabi, H., \& Al-Ghanimy, D. B. G., 2015. Determine the validity of the Euphrates River (Middle Euphrates) for drinking purpose using a water quality index (CCME WQI). Mesopotamia Environmental Journal, 2(1), $1-11$.

Camargo, J. A., Alonso, A., \& De La Puente, M., 2004. Multimetric assessment of nutrient enrichment in impounded rivers based on benthic macroinvertebrates. In Environmental Monitoring and Assessment 96(1-3), 233-249.

Camargo, J. A., Alonso, A., \& Salamanca, A., 2005. Nitrate toxicity to aquatic animals: A review with new data for freshwater invertebrates. Chemosphere, 58(9), 1255-1267.

Chabuk, A., Al-Madhlom, Q., Al-Maliki, A., Al-Ansari, N., Hussain, H. M., \& Laue, J., 2020. Water quality assessment along Tigris River (Iraq) using water quality index (WQI) and GIS software. Arabian Journal of Geosciences, 13(14).

Chen, J., \& Lu, J., 2014. Effects of land use, topography and socio-economic factors on river water quality in a mountainous watershed with intensive agricultural production in East China. In PLoS ONE 9 (8).

Chien, H., \& Pierce, K., 2018. Impacts of Changed Stream flow on Selected Water Quality Parameters in the Upper Esopus Creek Watershed of New York, USA. Journal Geographic Earth Science, 6(1), 71-78.

Hamid, A., Bhat, S. U., \& Jehangir, A., 2020. Local determinants influencing stream water quality. Applied Water Science, 10(1), 1-16.

Hanslík, E., Marešová, D., Juranová, E., \& Vlnas, R., 2016.Dependence of selected water quality parameters on flow rates at river sites in the Czech Republic. Journal of Sustainable Development of Energy, Water and Environment Systems, 4(2), 127-140.

Hussein, A., \& Bomola, A., 2013. Temporal and Spatial Changes in Water Quality of the Euphrates River - Iraq.

Lawrence, J. M., \& Gresens, S. E., 2004. Foodweb response to nutrient enrichment in rural and urban streams. In Journal of Freshwater Ecology, 19, (3),375-385.

Lee, G., Lee, H. W., Lee, Y. S., Choi, J. H., Yang, J. E., Lim, K. J., \& Kim, J., 2019. The effect of reduced flow on downstream water systems due to the Kumgangsan Dam under dry conditions. Water (Switzerland), 11(4), 1-20.

Mhaisen, F. T., Al-jawda, J. M., Asmar, K. R., \& Ali, M. H., 2017. Checklists of F ish P arasites of Al-Anbar P rovince, Iraq. Biological and Applied Environmental Research, 1(1), 17-56. 
Momblanch, A., Paredes-Arquiola, J., Munné, A., Manzano, A., Arnau, J., \& Andreu, J., 2015. Managing water quality under drought conditions in the Llobregat River Basin. Science of the Total Environment, 503-504, 300-318.

Niazi, F., Mofid, H., \& Fazel Modares, N., 2014. Trend analysis of temporal changes of discharge and water quality parameters of Ajichay River in four recent decades. Water Quality, Exposure and Health, 6(1-2), 89-95.

Prathumratana, L., Sthiannopkao, S., \& Kim, K. W., 2008. The relationship of climatic and hydrological parameters to surface water quality in the lower Mekong River. In Environment International, 34 (6), 860866).

Rahi, K. A., \& Halihan, T., 2010. Changes in the salinity of the Euphrates River system in Iraq. In Regional Environmental Change, 10 (1), 27-35.

Rostami, S., He, J., \& Hassan, Q. K., 2018. Riverine water quality response to precipitation and its change. Environments - MDPI, 5(1), 1-17.

Smith, V. H., Tilman, G. D., \& Nekola, J. C., 1999. Eutrophication: Impacts of excess nutrient inputs on freshwater, marine, and terrestrial ecosystems. In Environmental Pollution, 100 (1-3), 179-196.

Thu Ha, D. T., Kim, S. H., \& Bae, D. H., 2020. Impacts of upstream structures on downstream discharge in the transboundary imjin river basin, Korean Peninsula. Applied Sciences (Switzerland), 10(9).

Torrecilla, N. J., Galve, J. P., Zaera, L. G., Retamar, J. F., \& Álvarez, A. N. A., 2005. Nutrient sources and dynamics in a mediterranean fluvial regime (Ebro river, NE Spain) and their implications for water management. Journal of Hydrology, 304, (1-4), 166-182.

Venturi, L. A. B., \& Capozzoli, C. R., 2017. Changes in the water quantity and quality of the Euphrates river are associated with natural aspects of the landscape. Water Policy, 19(2), 233-256.

Yang, S. L., Xu, K. H., Milliman, J. D., Yang, H. F., \& Wu, C. S., 2015. Decline of Yangtze River water and sediment discharge: Impact from natural and anthropogenic changes. Scientific Reports, 5, 1-14.

Yunus, A. J. M., \& Nakagoshi, N., 2004). Effects of seasonality on streamflow and water quality of the Pinang River in Penang Island, Malaysia. In Chinese Geographical Science, 14, (2), 153-161. 